\title{
The History of Women by Men I: On the Phylogenetic Background of Gender Stereotypes
}

\author{
Julia Horvath Borbála \\ Corvinus University of Budapest, Hungary
}

Below described historical analysis is intended to provide a generic overview of how the notions of women and men were interpreted according to the stereotypes based on revelations of public thinkers; how these typologically formulated into stereotypes. And to what extent these are still present in public and private communication spaces. The hierarchical gender relationships are analyzed through texts, with critical approach towards the medium.

The basic assumption of the analysis is, that from a socio-philosophical approach, social order and its supporting theories were established based on androcentric principles. ${ }^{1}$ It was of crucial importance to create such functional and provisional spheres that ensured the control over the subordinate groups. Social communication and information technology served as means for manipulating public events, determining the opinion-shaping effects of open discourses and for institutionalizing dominance. ${ }^{2}$

\section{RESOURCES}

The research used classic theories and books of contemporary male thinkers as historical resources. The chosen texts were required to be works of well known, relevant thinkers, whose works or public discourses discussed gender roles, or whose theories or views dealt with females, though remaining ultimately male-centric(eg. Plato, Aristotle, etc...)

\section{GOALS}

The primary objective of this work is a critical interpretation of the historical correspondence and the social media of the discourses, analyzing the socio-philosophical effects of the female-related revelations, thus drafting the processes that lead to the establishment of gender stereotypes.

\section{METHODOLOGY}

The subject matter of the discussion required a careful choice of the correct methodology for the analysis of the historical background. The method that arose in the 1990's for the investigation of the mechanisms that created and sustained stereotypes seemed adequate at first, but preliminary studies of the discourses proved that the influence of the androcentric approach that penetrated the history of womankind is so strong even nowadays, that it should definitely be dealt with a critical approach. As a result, I focused on the assumption of above detailed critical discourse analysis, that the CDA evaluates the texts in the broader context of power relations (dominance, inequality, social background). ${ }^{3}$

Feminist discourse analyses focus mostly on the language critical position of the already established power relations (eg. deficit- dominance- difference), neglecting the historical reasons for their development (Lakoff, Tannen, Fishman). This phase of the analysis is thus consistently aiming the introduction of a socio-philosophical and communication-oriented perspective.

\section{The AnALYSIS}

I conducted a detailed investigation of the ancient conditions, especially the transition from matriarchy to patriarchy, when the classic elements of gender stereotypes were formed. Regarding

$1 \quad$ Hell, 2002: 322

2 Nagl- Docekal, 2006: 21- 49

3 van Dijk: 1994, Wodak: 2008 
matriarchy, I used the conclusions of ethnographic, anthropologic and art history researches as references, complemented with contemporary descriptions of the social structures of still existing matriarchal societies (eg. Morgan, Blackwood). Conclusions of more modern thinkers were discussed according to certain periods of feminism and their critical analysis (eg. first medieval rebels as the first feminist, the 1980's and the double standard of sexual morality, etc...).

Present phase of the analysis aims to describe the discursive fields that developed around such revelations, in other words, who wrote what and why, and how these influenced genders, especially the adjudication of women. My goal was to present the relevant characteristics of the eras when the revelations were said or written. Conclusions are included in the interpretation phase of the discourses.

The historical analysis was expected to clarify what stereotypes formed the notions of women and men based on the revelations of public thinkers, how these typologically formulated into stereotypes, and to what extent these are still present in public and private communication spaces. These were later investigated from the aspect of analyzing language stereotypes.

\section{From Matriarchy to Patriarchy}

When comparing matriarchy and the later established patriarchy, it is essential to evaluate the aspect of power, especially that of proprietorship. The historical partition of the ancient matriarchal social order happened presumably in the era of the Greek polis society, supposedly due to the deterioration of above mentioned values. ${ }^{4}$ The introduction of primogeniture initiated the patriarchal, paternal (Sun) era with unconditional male dominance that is identified as the foundation of modern civilization. Matriarchy was destroyed by the ideal state as defined by Plato. Critiques of his work were later evaluated by a contemporary pro-matriarchy researcher (Grandpierre) as follows: ${ }^{5}$

"As barbaric tribes misinterpret the key notions of the high-culture they destroyed, either for not being able to understand its real coherences, or for deliberately wanting to humiliate it, so will the central idea of magical activities less and less articular."

For Plato, accompanying each other for welfare was a dictate of common sense. His basic assumption was, that everyone is born with different skills and values -"that they are full of spirit almost as soon as they are born, whereas some of them never seem to attain to the use of reason, and most of them late enough." $"$ - accordingly, everyone has to fulfil an appropriate social role. As Plato continues:

"Citizens, we shall say to them in our tale, you are brothers, yet God has framed you differently. Some of you have the power of command, and in the composition of these he has mingled gold, wherefore also they have the greatest honour; others he has made of silver, to be auxiliaries; others again who are to be husbandmen and craftsmen he has composed of brass and iron;..."

Plato suggested getting the job done in smaller communities. He ordered the apportionment of goods, so that the codependence of the people in the community would result in an enhanced moral of cooperation; such as the different organs of the body, the community is also functioning as one organic unit. This concept resembled in many respects to matriarchy; however, at this point without involving the ultimate goal of power - that is prosperity. With time, the community would grow bigger, and Plato also had to be more realistic: ${ }^{7}$

“(...) But if you wish also to see a State at fever-heat, I have no objection. For I suspect that many will not be satisfied with the simpler way of life. They will be for adding sofas,

4The Etruscan society was matriarchal and exogenous; the right of successiondid not belong to male ascendants. With the death of Tarquinius; however, the notions of land- and private ownership, family and patriarchy slowly penetrated into society.Women in the Roman Empire had a more difficult situation than in greek societies: they were subordinate to wealth, considered as "means" for gaining and trading properties, without any protection from family rights, unable to take part in public affairs to vindicate their rights.

5Same resource as above

6 Plato, 2001. book IV: 72

7 Plato, same resource.: 50 
and tables, and other furniture; also dainties, and perfumes, and incense, and courtesans, and cakes, all these not of one sort only, but in every variety; we must go beyond the necessaries of which I was at first speaking, such as houses, and clothes, and shoes: the arts of the painter and the embroiderer will have to be set in motion, and gold and ivory and all sorts of materials must be procured."

As he wanted to put an end to uneven acquisition of power and wealth, he also detailed the egalitarian adjudication of women and men. Unlike the dominant stereotypes of posterior patriarchal systems, he positioned women as being more or less equal to men. Though there is no significant differentiation between male and female features in his patriarchal republic-theory, Plato considered equality within the frames of economic rationality (eg. guards). In his opinion, removing one half of the community from common duties was not beneficial, moreover, as active members of the community, it was not sufficient for women to do houseworks and parenting only. As a consequence, he asked the question that seems so familiar: Is it good and beneficial to involve women into governmental duties: ${ }^{8}$

- Is female nature the same as that of malesor is it different?

- Do these features mean natural born or acquired skills?

- Do women have the same capabilities as men?

Aristotle and gender hierarchy

The dissolution of matriarchy was followed by the polis society, where Plato did not doubt the equality of women and men - he even considered the interchange of gender roles (eg. parenting) as a possible. Though the ideas of matriarchy were wanly present in his discourse, with time, students were less and less likely to follow the ideology of the precious order. As the hierarchy of intellect and emotions got widespread, the leader/man/intellect concept became superior to the artificially downgraded desire/woman/emotion stereotype. (Theoretical identification of women and men, the endeavor towards gender equality only appeared in the XIX- XX. century again.)

Plato's student, Aristotle; however, followed a more radical path regarding the questions of men and women - he openly opposed, for instance, the female-children related joint estate system as described in The Republic-and his gender paradigm evolved into a determining factor of European culture. Modern social gender relations most likely originate from this theory as well, implying that men should be active in the power- and wealth-oriented spheres, whereas women should remain servants in the background spheres. Below quoted discourses were publicly performed, having an inestimably negative effect on women, as rhetors' statements were widespread by pundits without any criticism from the audience. Most quotes are taken from Aristotle's work Politics. Aristotle's statements on genders were not as thorough and accurate as his spiritual heritage in all other fields. Male dominance was assumed a priory, and his experience justifying its premises were published without contraindications. The universality of such theories had never been doubted throughout the following centuries either. When describing social order, he claimed: republic is a community or association of men and women, citizens and servants, whose relationship is at all levels mutual; however, a qualitybased distinction must be made. ${ }^{9}$

"Again, the male is by nature superior, and the female inferior; and the one rules, and the other is ruled; this principle, of necessity, extends to all mankind.

Where then there is such a difference as that between soul and body, or between men and animals (as in the case of those whose business is to use their body, and who can do nothing better), the lower sort are by nature slaves, and it is better for them as for all inferiors that they should be under the rule of a master."

Aristotle took the subordinate status of women as a kind of natural hierarchy, thus excluding female vindication from politics. According to his theory, men and woman cannot be equal due to their

8 Aristotle, Hegel, Kant, Marx, Spinoza- they all used the term "human nature", though with various meaning. Above questions focus on diversity, and the basic assumption of the approach determines the investigation of the significant elements (eg. is mind a part of human nature at all?)

9 Aristotle, Politics, 1994: 5 
original nature that is a natural born essence. Guidance over women was a political need, and in his view, this division supported and promoted social functionality. He made; however, a distinction between guidance over women and that of over children. Latter was considered superior to the other, for its lovefulness and the justifying power of the elderly (parent). This later lead to the essentialist theory that differentiated between female and male brains: the male intellect-female emotions, and the virtue-sin as exclusive binary gender oppositions. ${ }^{10}$ Aristotle made a distinction regarding morals as well:

"...the temperance of a man and of a woman, or the courage and justice of a man and of a woman, are not, as Socrates maintained, the same; the courage of a man is shown in commanding, of a woman in obeying. "11

The creation of the man-woman contradistinction and the description of their hierarchical relationship were also based on these thoughts, that later became the doctrine for feminist criticism. ${ }^{12}$ The abstraction of the contradictory oppositions, such as body and mind, form and material, good and bad, valuable and worthless, light and dark, all became fundaments of male-female relationship-system as positive or negative categories, formulating a determining logos of gender interactions. All this was completed by the essentialist statement that: „For although there may be exceptions to the order of nature, the male is by nature fitter for command than the female (...)". ${ }^{13}$ The so established social gender order was taken as a universal axiom. Aristotle:

"If, however, there be some one person, or more than one, although not enough to make up the full complement of a state, whose virtue is so pre-eminent that the virtues or the political capacity of all the rest admit of no comparison with his or theirs, he or they can be no longer regarded as part of a state; for justice will not be done to the superior, if he is reckoned only as the equal of those who are so far inferior to him in virtue and in political capacity. Such as one may truly be deemed a God among men. "14

From a female point of view, the so constituted gender hierarchy can be interpreted as a polarized hierarchical system, such as aristocracy, where a chosen group of people rules over the other group. In case of gender aristocracy - unlike in case of the limited number of members in the classical aristocracy - the number of rulers more or less equals to that of the subordinates (men and women). The idea, that the constitutional dependency, subordination and infantilization of women served common wealth, was used as justification, though being contradictory to the fundamentals of the actual paradigm, democracy. Aristotle explains:

"It must not be assumed, as some are fond of saying, that democracy is simply that form of government in which the greater number are sovereign, (...) Therefore we should rather say that democracy is the form of government in which the free are rulers, "15

Socrates was more permissive than Aristotle when dealing with male-female virtues. In his discourse, the difference between the virtues of men and women are only proportional and not qualitative. His milder opinion was supported by the fact that he was willing to give wome the right to participate at public meals, a privilege of those in power. Aristotle; however, opposed all privileges and ideas in connection with equality, for that would lead to an overly familiarized state. He continued to hold on to his idea, that women are ,the most unholy and the most savage of animals, and the most full of lust and gluttony., 16

10 The concepts of man and woman were originally created to record the different physical features according to the distinctive primary and secondary biological gender features. As a result, when discussing social gender roles, the notions of eg.male and female duties originally carried an entirely different, complex background meaning. This assumption implies numerous dilemmas, eg: if, according to the stereotype, male duties are more valuable than female jobs, the quality of the worker becomes limited, creating a power hierarchy without considering skills and real results. Docekal, 2006: 175- 184

11 Same resource, Book II.

12 Aristotle: same resource and Aristotle - Metaphysics. Nagl- Docekal, 2006: 175- 195

13 Aristotle, Book I. Section 9b

14 Book III. Section 4a.

15 Same resource, Book IV. k. section 4

16 Same resource. 
Male-centered mentality got widespread and stabilized. Aristotle explained the occurrence of the seldom and moderate rebellions of women in the background as follows:

"The universal and chief cause of this revolutionary feeling has been already mentioned; viz., the desire of equality, when men think that they are equal to others who have more than themselves; or, again, the desire of inequality and superiority, when conceiving themselves to be superior they think that they have not more but the same or less than their inferiors; pretensions which may and may not be just. Inferiors revolt in order that they may be equal, and equals that they may be superior." 17

In his understanding, dissatisfaction and discordance are results of the endeavor for profit and prestige, which implies, to some extent, either gaining more or preserving the existing powers. All disagreement issues in aristocracy are consequences of the dissatisfaction of the parties displaced from ruling powers, when receiving an important leading function remains the privilege of the top few of the ones that have the aptitude. After a while, the constitution amends in favor of the ones who demand change, so the rebels finally reach their goals. Such a result; however, cannot be a triumph for women, as Aristotle described an eventual female authority as an extremity of democracy:

"Again, the evil practices of the last and worst form of democracy are all found in tyrannies. Such are the power given to women in their families in the hope that they will inform against their husbands, and the license which is allowed to slaves in order that they may betray their masters; for slaves and women do not conspire against tyrants; and they are of course friendly to tyrannies and also to democracies, since under them they have a good time. For the people too would fain be a monarch, and therefore by them, as well as by the tyrant, the flatterer is held in honor; in democracies he is the demagogue; and the tyrant also has those who associate with him in a humble spirit, which is a work of flattery." 18

As for mastery and agreement, he indeed drafted a solution, describing a method applicable in gender hierarchy in case of an eventual gender democracy as dysfunction:

“(...) For the actions of a ruler cannot really be honorable, unless he is as much superior to other men as a husband is to a wife, or a father to his children, or a master to his slaves. And therefore he who violates the law can never recover by any success, however great, what he has already lost in departing from virtue. For equals the honorable and the just consist in sharing alike, as is just and equal. But that the unequal should be given to equals, and the unlike to those who are like, is contrary to nature, and nothing which is contrary to nature is good." 19

Silence remained a woman's glory, whereas the same feature meant dysfunction among males, as "he would seem as immature as an unknowing child. ${ }^{, 20}$

\section{IN SUMMA}

The adjudication of matriarchy is rather ambivalent. In spite of contemporary states with similar social structures, its existence is only dealt with in connection with matrilineal succession. In the so called classic matriarchy, power and authority belong to women. Their privileged position is an automatic and practically present structure, forming a solid base for subsistence and race preservation. Matriarchy in ancient and modern times is described as a hierarchical formula without an aggressive executive force, not dominated by violence and forceful collection of material goods. A society, where crime and abuse are unknown notions, there are no state institutions for authority enforcement and no central religious organizations.

According to patriarchal principles, the idea of a non-male master or leader has been considered as heresy in both public- and private life. From the aspect of gender relations, ever since the dissolution of matriarchy, potent candidates for above mentioned virtues (requirements) could exclusively be men. The terminology of men or people referred only for the male, women and mothers, who did play a significant role in the creation of the nation, were excluded. Women and children were ranked as property items of the men.

17 Book V. section 2a

18 V. section XI.

19 VII. Section III

20 Morus, 1989: 65 
Social order and hierarchical subordination relations were defined according to the way power was practiced - in ancient societies, in order to became a full citizen, the only requirement was to be born a male, in the census, it was enough to certify citizen origin through three or four generations.

Besides origin and properties, education also became a privilege, thus with the exclusion of women, that served the establishment of a kind of gender aristocracy, with the male being exclusively eligible for power.

As a conclusion, an important state-organizational dilemma may arise: in modern democracy, can the system of female rights and equality be based on an ancient structure, where the significant other (female) half of the community was simply not allowed to represent themselves in public life equally and in a rightful proportion?

\section{BIBLIOGRAPHY}

Arisztotelész: Politika. Gondolat, 1994. MEK

Docekal, Herta Nagl: Feminista filozófia. Ford: Hell Judit. Áron Kiadó, Budapest, 2006

Dijk, van, Teum A: A kritikai diskurzuselemzés elvei. In.: Szabó Márton- Kiss Balázs- Boda Zsolt: Szövegváltozatok a politikára. Nyelv, szimbólum,retorika, diskurzus. Nemzeti Tankönyvkiadó Univesitas. 2000

Hell Judit: Van-e feminista filozófia? Áron Kiadó, Budapest, 2006

Morus Tamás: Utópia, Európa Könyvkiadó, Bp., 1989

Platón: Az állam. Lazi, 2001. MEK/ http://mek.niif.hu/03600/03629/03629.htm. (ford.: Palo: The Republic. The Secret History of the Soul: Physiology, Magic and Spirit Forces from Homer to St Paul)

Wodak, Ruth and Meyer, Michael: Methods of Critical Discourse Analysis (Introducing Qualitative Methods series) Abridged. 2001

\section{AUTHOR's BIOGRAPHY}

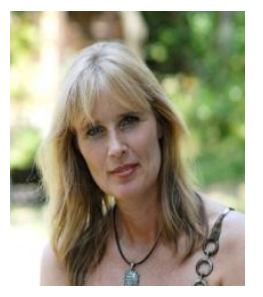

Júlia Horváth Borbála, Cultural anthropologist, researcher, writer. Budapest Corvinus University (BCE) - Social Communication DI.

She's been doing publications on female stereotypes of the XXI century (description of the concept system of intermentality) for over 10 years. She has also been lucky enough to work as documentary filmmaker (men's and women's crafts), as journalist and as musician. She managed thematic website, including her sciense results and literature works. Her passion for researching on women's roles in aspect of intermentality. HJB's books: New Woman Age entitled - collection of cultural anthropologist studies on the modern female era. (L' Harmattan, 2008). GirlGill entitled-collection of essays on history of philosophy (L'Harmattan, 2015). So far she have published essays and shorter works of science and literature; right now her work is supported by a minor NKA-scholarship. 